\title{
Application of Nitrifying and Denitrifying Processes to Waste Management of Aquatic Life Support in Space
}

\author{
Ryuji Shimura $^{1,2}$, Hidenori Kumagai $^{1}$, Hiromi Kozu ${ }^{1}$, Shigeru Motoki ${ }^{1}$, Kenichi Ijiri ${ }^{3}$ and Shunji Nagaoka ${ }^{4}$ \\ ${ }^{1}$ Advanced Engineering Services Co., Ltd., Takezono, Tsukuba, Ibaraki 305-0032, Japan \\ ${ }^{2}$ Graduate School, Toyama University, Gofuku, Toyama, Toyama 930-8555, Japan \\ ${ }^{3}$ Radioisotope Center, University of Tokyo, Yayoi, Bunkyo-ku, Tokyo 113-0032, Japan \\ ${ }^{4}$ Fujita Health University School of Health Sciences, Toyoake, Aichi 407-1192, Japan
}

\begin{abstract}
Since a biological filter with nitrifying bacteria was firstly applied to aquatic animal experiments in IML-2 mission, the reactor system has been further studied to combine both nitrifying and denitrifying reactions under aerobic environment allowing an efficient removal of inorganic nitrogen from animal wastes. The isolated denitrifying bacteria had an activity under aerobic condition with rice straw providing a metabolic carbon source for the reaction. The advantage of the aerobic biological filter having both nitrifying and denitrifying activities may allow to reduce the size of the life support system and also for its manageability. The paper reports characteristics of the biological filter systems used for the IML-2 mission and the improved combined filter system having both nitrifying and denitrifying activities, and discuss its application to space experiments.
\end{abstract}

Keywords; Biological filter, Nitrifying bacteria, Denitrifying bacteria, Rice straw, Nitrate toxicity

\section{Introduction}

We have studied a compact life support system for multi-generation studies of medaka in Space Station. An important issue for aquatic animal experiments in space, as well as on the ground, is to remove toxic nitrogen waste from water environment. Aquatic animals produce nitrogenous wastes and cause an ammonia accumulation in the living environment. The accumulation of ammonia is the primary toxin in the water environment. Nitrifying bacteria oxidizes ammonia waste progressively into less toxic substances by two steps. The ammonia is firstly converted to nitrite $\left(\mathrm{NO}_{2}^{-}\right)$by an ammonium oxidizing bacteria, and secondary the nitrite is converted to the least toxic nitrate $\left(\mathrm{NO}_{3}{ }^{-}\right)$by a nitrite oxidizing bacteria. The successful result was obtained by applying a nitrifying filter system to the aquatic animal holding in the second International Microgravity Laboratory (IML-2) mission in 1994 (NASDA, 1996). Although nitrate is the least toxic among the inorganic nitrogen compounds, the effects to fish for long-term exposure may not be negligible even under a low concentration. Based on the past experiences of the space experiments, an addition of denitrifying process is one of the issues for improving the biological filter system. The purpose of the denitrifying process is to totally remove toxic inorganic nitrogen compounds from the system as nitrogen gas form. A typical denitrifying reaction by bacteria requires anaerobic condition and organic carbon

Original Paper

Received: December 15, 1999.

Accepted: December 30, 1999.

Address for correspondence: Ryuji Shimura

r_shimura@aes.co.jp sources as an electron donor such as carbohydrate, alcohol or organic acids (Meiklejohn, 1940; Rhodes et al., 1963; Davies and Toerien, 1971; Rhee and Fuks, 1978; Blaszczyk et al., 1980). We recently found that bacteria on rice straw have denitrifying capability under aerobic conditions and the rice straw itself can be used as carbon sources for the reaction. It is then desired that the aerobic denitrifying may be applied to solve the issue of anaerobic methods. This paper reports the toxicity of accumulated nitrate with medaka using simple nitrifying filter system and characteristics of improved aerobic combined filter system including both nitrifying and denitrifying activities.

\section{Materials and Methods}

\section{Nitrifying filter}

Bacteria isolation and filter preparation:Although we attempted to isolate nitrifying bacteria from an activated sludge, the bacterial activity was not stable under a low ammonium environment. We then directly isolated the nitrifying bacteria from the skin surface and a mucous membrane of goldfish in a well-balanced aquarium, as shown in Fig. 1, and cultured to activate the filter media for space experiment apparatus, AAEU. The activity of the bacteria isolated from the fish was high enough even under low ammonium concentration. The filter media used was porous sintered glass beads in 2 to $3 \mathrm{~mm}$ diameter (Siporax, Schott). Their highly porous structure is particularly suitable for colonization of bacteria. To simulate the space experiment, $230 \mathrm{~cm}^{3}$ filter media was set into the filter units in the life support system which include $5 \mathrm{~L}$ water with circulation velocity, $8-10 \mathrm{~cm} / \mathrm{min}$. Stabilization of the filter was performed with 5 goldfish (7.0-10.5g in weight, 7.5$12.0 \mathrm{~cm}$ in length). The water used was a commercial natural 


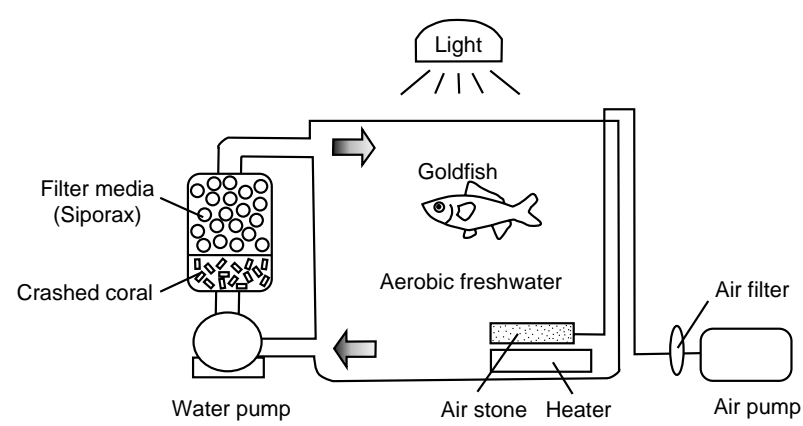

Fig.1 Experimental set up for isolation and culture of nitrifying bacteria with Siporax filter.

Water volume: $5 \mathrm{~L}$ for isolation and $8 \mathrm{~L}$ for culture, total siporax volume: $230 \mathrm{~cm}^{3}$ for isolation and $1000 \mathrm{~cm}^{3}$ for culture, circulation velocity: $8-10 \mathrm{~cm} / \mathrm{min}$, oxygen supply: air bubbling, crashed coral: $50 \mathrm{~cm}^{3}$ for isolation and $200 \mathrm{~cm}^{3}$ for culture, water temperature: $23 \pm 1{ }^{\circ} \mathrm{C}$, light cycle: 14 -hrs light and 10-hrs dark, $\mathrm{pH}$ : 6.5-8.0, water change: $30 \%$ when $\mathrm{NH}_{4}{ }^{+}-\mathrm{N}>10$ or $\mathrm{NO}_{2}{ }^{-}-\mathrm{N}>15 \mathrm{mg}-\mathrm{N} / \mathrm{L}$ during isolation and $50 \%$ every 2 days for culture.

water containing $10 \mathrm{mg}-\mathrm{P} / \mathrm{L}$ phosphate buffer $(\mathrm{pH} 7.5)$ and $0.5 \mathrm{ml} / \mathrm{L}$ of concentrated mixed mineral solution (Shimura et al., 1995). The water temperature was kept at $23 \pm 1^{\circ} \mathrm{C}$. We carefully maintained the ammonium and nitrite concentrations below $10 \mathrm{mgNH}_{4}{ }^{+}-\mathrm{N} / \mathrm{L}$ and $15 \mathrm{mgNO}_{2}{ }^{-}-\mathrm{N} / \mathrm{L}$ respectively to avoid the toxicity by partial water change (30\% per each time). The $\mathrm{pH}$ of water was maintained 6.58.0 by adding $50 \mathrm{~cm}^{3}$ crushed coral into the filter unit and the water change. The activities were evaluated by an ammonium consumption rate, $\mathrm{V}_{\mathrm{NH} 4}\left(\mathrm{mgNH}_{4}{ }^{+}-\mathrm{N} / 100 \mathrm{~cm}^{3}\right.$ filter/day) for ammonium oxidation, and by an initial nitrite accumulation rate, $\mathrm{V}_{\mathrm{NO} 2}\left(\mathrm{mgNO}_{2}-\mathrm{N} / 100 \mathrm{~cm}^{3}\right.$ filter/day) for nitrite oxidation, because the intermediate reaction rate could not be measured in the simultaneous reaction. We then define a 'balance index', 100( $\left.\mathrm{V}_{\mathrm{NH} 4}-\mathrm{V}_{\mathrm{NO} 2}\right) / \mathrm{V}_{\mathrm{NH} 4}$ which varies from 0 to 100 , where 100 indicates completely balanced. Assays for ammonium and nitrite concentrations were made by indophenol and Griess-Romijn methods respectively, nitrate concentration was analyzed by brucine method or cadmium reduction method.

The balanced filter media containing nitrifying bacteria was used as the seeds for expand the volume by mixing $100 \mathrm{~cm}^{3}$ seeds with $900 \mathrm{~cm}^{3}$ new medium in $8 \mathrm{~L}$ water with 8 goldfish. Bacteria growth was accelerated by additions of $5 \mathrm{mg}-\mathrm{N} / \mathrm{L}$ ammonium sulfate every 2 days after 10 days of pre-cultivation with 14-light and 10-dark control. The $\mathrm{pH}$ was also maintained by the same method describe above $\left(200 \mathrm{~cm}^{3}\right.$ of crashed coral, $50 \%$ water change/2 days).

Characterization of nitrifying filter: We evaluated the isolated bacteria on the effects of $\mathrm{pH}$ and ammonium concentration. To determine the $\mathrm{pH}$ dependency of the nitrifying bacteria colonized on the filter media, the activity was measured using buffered medium at various $\mathrm{pH}$. The $\mathrm{pH}$ of medium was changed to $6.0,6.5,7.0,7.5$ and 8.0 by phosphate buffer. The nitrifying activity was assayed by adding 5mg-N/L ammonium sulfate. The ammonium

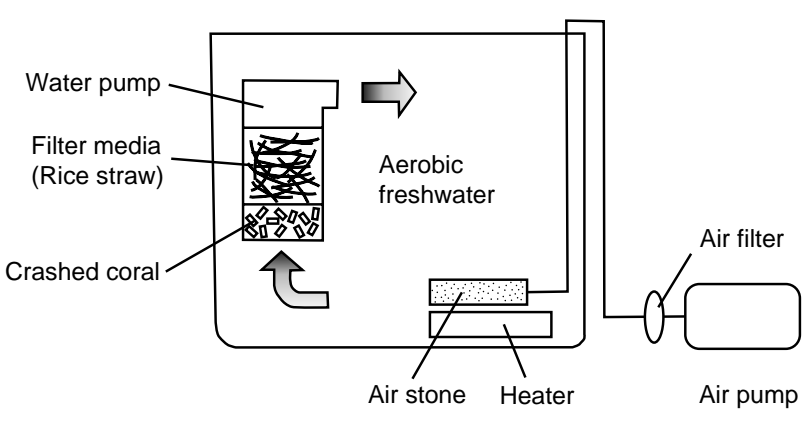

Fig.2 Experimental set up of denitrifying bacteria culture with rice straw filter.

Water volume: $10 \mathrm{~L}$, rice straw: $10 \mathrm{~g}$ (dry weight), circulation velocity: $25-30 \mathrm{~cm} / \mathrm{min}$, oxygen supply: air bubbling, crashed coral: $50 \mathrm{~g}$, water temperature: $25 \pm 1^{\circ} \mathrm{C}, \mathrm{pH}: 7.2-7.6$.

dependency of the nitrifying activity was measured under concentrations of 5, 10, 20, 50 and 100mg-N/L ammonium sulfate with 5 consecutive times at $\mathrm{pH} 7.5$. The experiments were performed using $100 \mathrm{~cm}^{3}$ filter unit in $1 \mathrm{~L}$ test medium at $23 \pm 1^{\circ} \mathrm{C}$. The culture medium was prepared with water purified by reverse osmosis containing $50 \mathrm{mg}-\mathrm{P} / \mathrm{L}$ of phosphate buffer, $10 \mathrm{mg}-\mathrm{Ca} / \mathrm{L}$ and $0.5 \mathrm{ml} / \mathrm{L}$ mixed mineral solution. The crushed coral was not added for this assay.

Nitrifying filter for IML-2 mission: Fundamental requirements of the biological filter system in AAEU were; 1) optimum $\mathrm{pH}$ of the nitrifying activity near $\mathrm{pH} 7.5$ at $23^{\circ} \mathrm{C}$, 2) a minimum nitrifying capability was $1.6 \mathrm{mgNH}_{4}{ }^{+}-\mathrm{N} /$ $100 \mathrm{~cm}^{3}$ filter/day, and 3 ) both ammonium and nitrite concentrations should be maintained below $1 \mathrm{mg}-\mathrm{N} / \mathrm{L}$ over 19 days. The filter prepared fully satisfied the requirements, and indicated activity $17.7-20.9 \mathrm{mgNH}_{4}{ }^{+}-\mathrm{N} / 100 \mathrm{~cm}^{3}$ filter/ day at initial (Table 1). The water used for flight experiment was the natural water containing additional $10 \mathrm{mg}-\mathrm{P} / \mathrm{L}$ of phosphate buffer and $0.5 \mathrm{ml} / \mathrm{L}$ of mixed mineral solution. The nitrifying activity in AAEU (both flight and ground control) was evaluated at $112 \mathrm{hrs}$ before launch and 11 and $35 \mathrm{hrs}$ after landing by additions of ammonium sulfate.

\section{Combined aerobic nitrifying and denitrifying filter}

Isolation and culture of denitrifying bacteria:Among many species of bacteria on the rice straw, we found that only heat-resistant Bacillus sp. was responsible for denitrifying reaction. The major part of bacteria isolation was simple boiling process in water at $100^{\circ} \mathrm{C}$ for $20 \mathrm{~min}$. We evaluated the effect of denitrifying activity of intact and boiled rice straws in aerobic freshwater. The activity was determined by a nitrate consumption rate after addition of potassium nitrate $(20 \mathrm{mg}-\mathrm{N} / \mathrm{L})$ expressed as $\mathrm{mgNO}_{3}{ }^{-} \mathrm{N} /$ $10 \mathrm{~g}$-rice straw/day. The measurement was performed using $10 \mathrm{~g}$ (dry weight) of intact and boiled rice straws in $10 \mathrm{~L}$ water at $25 \pm 1^{\circ} \mathrm{C}, \mathrm{pH} 7.2-7.6$ in the presence of $50 \mathrm{~cm}^{3}$ crashed coral. The intact and the boiled rice straws were set into the canister of the internal filter system, as shown in Fig. 2, and aerobic nitrate solution was circulated in 25- 


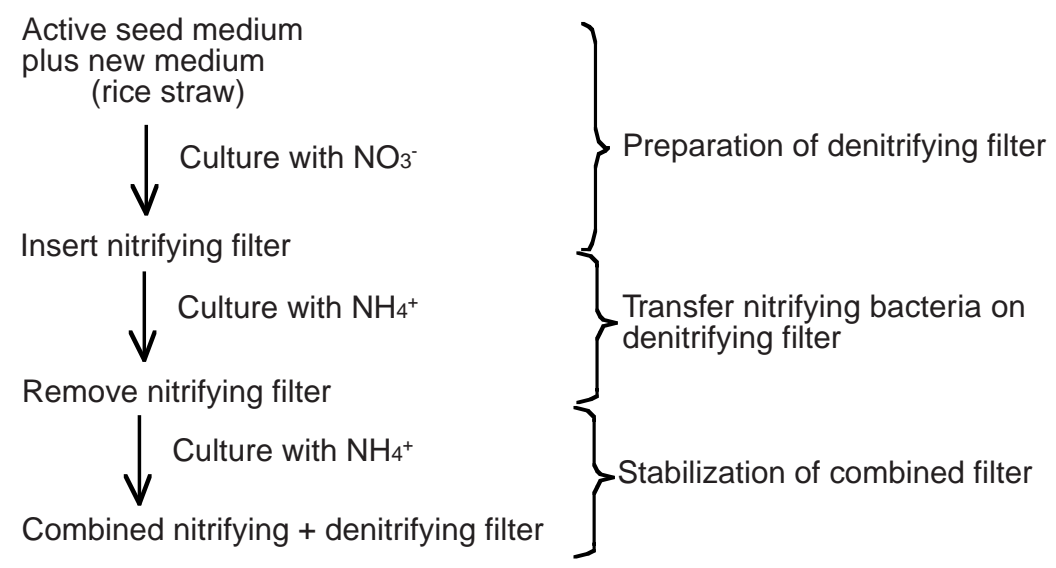

Fig.3 Procedure outline of preparation of the combined filter with rice straw.

$30 \mathrm{~cm} / \mathrm{min}$ linear velocity.

The rice straw having high denitrifying activity was used for inoculation using the same apparatus as shown in Fig. 2. The denitrifying bacteria were maintained with rice straw by the inoculation method with mixing ratio of 1:9 in volume. The activity assay during culture was the same method described previously.

Preparation of combined filter:Fig. 3 shows a preparatory process of the combined filter. The nitrifying bacteria used for the combined filter was essentially the same as described in the previous section, the porous sintered glass holding nitrifying bacteria from goldfish. The nitrate and ammonium concentrations added were $20 \mathrm{mgNO}_{3}{ }^{-}-\mathrm{N} / \mathrm{L}$ and $5 \mathrm{mgNH}_{4}{ }^{+}-\mathrm{N} / \mathrm{L}$ respectively. The combined filter was prepared by mixing $50 \mathrm{~cm}^{3}$ of the nitrifying filter of Siporax with $10 \mathrm{~g}$ of the denitrifying filter of rice straw in the culture medium containing $5 \mathrm{mg}-\mathrm{N} / \mathrm{L}$ ammonium sulfate. The nitrifying filter was then removed after the nitrifying bacteria were transferred to the denitrifying filter side, normally the process took for 7 days. The culture was continued to stabilize nitrifying and denitrifying activities.

Nitrifying and denitrifying processes: When the nitrifying bacteria were transferred to the denitrifying filter, we could observe both nitrifying and denitrifying processes occurred on the same filter. Since the denitrifying process normally required nitrite as substrate, two reactions, an

Table 1 Condition of the biological filters used in IML-2.

FM: flight unit, BBM: ground control unit, AP included newt and medaka, FP included goldfish.

The activity of BBM-AP in parentheses was an estimated value. The filter was prepared from the same source of media as FMAP.

\begin{tabular}{|c|c|c|c|c|}
\hline & \multicolumn{2}{|c|}{ FM } & \multicolumn{2}{c|}{ BBM } \\
\cline { 2 - 5 } & AP & FP & AP & FP \\
\hline $\begin{array}{c}\text { Nitrifying Acutivity } \\
\left(\mathrm{mgNH}_{4}-\mathrm{N}_{1} \text { 100 } \mathrm{cm}^{3} \text { filter/day }\right)\end{array}$ & 17.7 & 20.9 & $(17.7)$ & 20.8 \\
\hline $\begin{array}{c}\text { Filter Volume } \\
\left(\mathrm{cm}^{3}\right)\end{array}$ & 220 & 300 & 220 & 300 \\
\hline $\begin{array}{c}\text { Water Volume } \\
(\mathrm{L})\end{array}$ & 2.76 & 5.12 & 3.12 & 5.48 \\
\hline
\end{tabular}

oxidation of nitrite to nitrate by nitrifying process and a reduction of nitrate to nitrite by the denitrifying process, appeared to occur simultaneously. To confirm those processes, we prepared three types of filters which had different activity ratios of the two processes (nitrifying<denitrifying, nitrifying denitrifying, nitrifying > denitrifying). In those three types of filters using $10 \mathrm{~g}$ rice straw, the denitrifying activity $\left(25 \mathrm{mgNO}_{3}{ }^{-} \mathrm{N} / 10 \mathrm{~g}-\right.$ rice straw/day) was kept constant and changed the nitrifying activity to $12.5,25$ and $50 \mathrm{mgNH}_{4}{ }^{+}-\mathrm{N} / 10 \mathrm{~g}$-rice straw/day. The water used for the evaluation was $10 \mathrm{~L}$ and maintained aerobic condition. The experiment was performed at $25 \pm 1^{\circ} \mathrm{C}$ and $\mathrm{pH} 7.2-7.6$. The concentrations of nitrate and ammonium slats added for assays were $10 \mathrm{mgNO}_{3}{ }^{-}-\mathrm{N} / \mathrm{L}$ and $10 \mathrm{mgNH}_{4}{ }^{+}-\mathrm{N} / \mathrm{L}$ respectively.

Filter capacity measurement:Since the denitrifying process required organic carbon sources, there is a limited capacity of nitrate removal. To estimate maximum capacity of the rice straw as the organic carbon source of the denitrifying reaction, we continued to maintain the filter activity by adding known amount of ammonium sulfate until it broke down. The tests were conducted in 3 different intervals of ammonium addition using the same apparatus as described with $10 \mathrm{~g}$ of rice straw having balanced activities (nitrifying<denitrifying) in $10 \mathrm{~L}$ water. Each ammonium addition was kept constant, $5 \mathrm{mgNH}_{4}-\mathrm{N} / \mathrm{L}$, and continued with 3 different intervals, 3, 6, 9 days. Entire experiment was repeated 3 times.

\section{Nitrate toxicity on medaka development}

The toxicity of nitrate to medaka (Oryzias latipes) was evaluated by $50 \%$ lethal concentrations (LC50) at $96 \mathrm{hrs}$ after acute exposure of fry and also the delay of hatching time of eggs under continuous exposure to nitrate from the fertilization. Three stages of medaka fry were used for the LC50 evaluation, just after hatching, one and two months after hatching. We observed development of fertilized eggs to measure the hatching time. The test procedure was employed from a method of Organization for Economic Cooperation and Development guideline for testing chemicals (OECD, 1981), the toxicity was evaluated in 5 

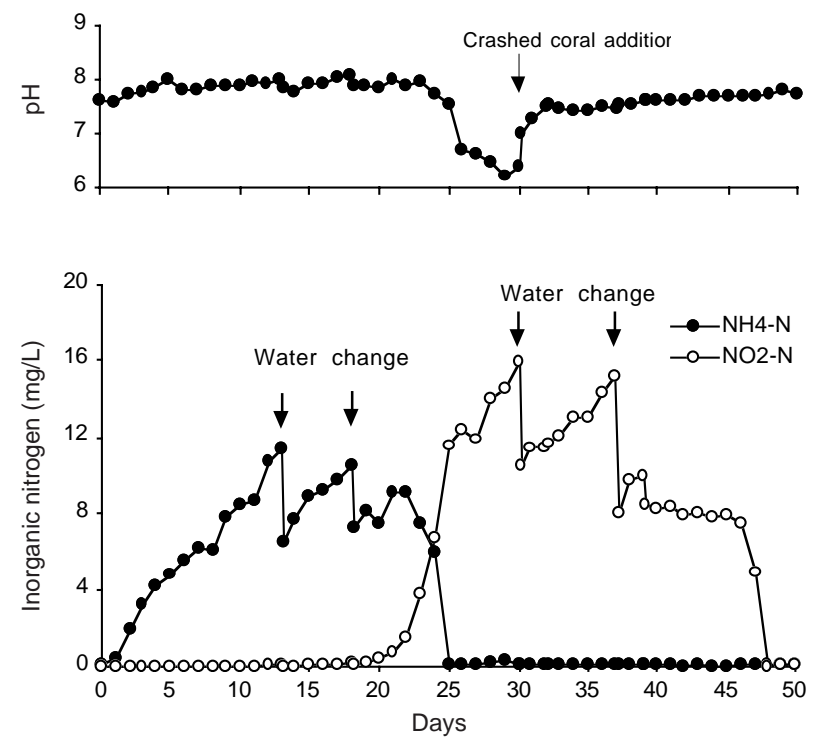

Fig.4 A typical profile of activity growth during the isolation of nitrifying bacteria from goldfish.

Upper figure: water $\mathrm{pH}$, lower figure: solid circle; ammonium concentration, open circle; nitrite concentration.

concentrations within a minimum lethal level. In the tests of the acute toxicity and the hatching retardation, 10 fry and 20 eggs were used as one group respectively. Each test was repeated 5 times in $60 \mathrm{ml}$ water for egg or $2 \mathrm{~L}$ water for fry at a temperature, $25 \pm 0.5^{\circ} \mathrm{C}, \mathrm{pH} 7.4-7.8$, and with 14hrs light and 10-hrs dark cycle. The hatching retardation was carried out in a nitrate concentration range, 0 $250 \mathrm{mgNO}_{3}{ }^{-}-\mathrm{N} / \mathrm{L}$ with $50 \mathrm{mg}-\mathrm{N} / \mathrm{L}$ interval based on the $\mathrm{LC}_{50}$ value. We carefully maintained the ammonium and nitrite concentrations as low as possible to a negligible level by using a well-balanced nitrifying filter system.

\section{Egg-to-egg experiment of medaka}

To evaluate a performance and the stability of the combined filter with rice straw, we selected a egg-to-egg experiment of medaka using 3 sets of apparatus. Each set included 10 eggs in $10 \mathrm{~L}$ water keeping at $25 \pm 1^{\circ} \mathrm{C}$, pH7.68.2 with 14-hrs light and 10-hrs dark cycle. The nitrifying and the denitrifying activities of the filter ( $10 \mathrm{~g}$ of rice straw) were $12.5 \mathrm{mgNH}_{4}{ }^{+}-\mathrm{N} / \mathrm{day}$ and $25 \mathrm{mgNO}_{3}{ }^{-} \mathrm{N} / \mathrm{day}$ respectively. The feeds for medaka were Super gold

Table 2 Toxicity and retardation effect of nitrate to medaka fry. Test subjects 10 fry and 20 eggs were used as one group. Each test was repeated 5 times. The LC 50 value was calculated by Probit analysis.

\begin{tabular}{|c|c|c|c|c|}
\hline \multicolumn{2}{|c|}{ Acute Toxicity } & \multicolumn{3}{|c|}{ Hatching Retardation } \\
\hline Age & $\begin{array}{c}96 \mathrm{hrs} . \mathrm{LC} 50 \\
\left(\mathrm{mgNO}_{3}-\mathrm{N} / \mathrm{L}\right)\end{array}$ & $\begin{array}{c}\mathrm{NO}_{3}^{-}-\mathrm{N} \\
(\mathrm{mg} / \mathrm{L})\end{array}$ & $\begin{array}{c}\text { Delay } \\
\text { (days) }\end{array}$ & $\begin{array}{c}\text { Relative } \\
\text { Population } \\
(\%)\end{array}$ \\
\hline Just hatched & 156 & 150 & non & non \\
\hline 1 month & 116 & 200 & $4-5$ & $40-50$ \\
\hline 2 months & 166 & 250 & $5-7$ & $95-100$ \\
\hline
\end{tabular}

(Oriental Yeast) in early stage fry until one month and TeraMin (Tetra) for fry after one month, both including $45-50 \%$ crude proteins. The daily amount of the feeding was $8-10 \%$ of the fish weight. A loss of water evaporation was replenished by adding same amount of water. One system having a nitrifying filter was used as a control to evaluate effects of nitrate accumulation. The $\mathrm{pH}$ was maintained by including $100 \mathrm{~cm}^{3}$ crashed coral in the system. The concentrations of inorganic nitrogen $\left(\mathrm{NH}_{4}{ }^{+}-\right.$ $\left.\mathrm{N}, \mathrm{NO}_{2}^{-}-\mathrm{N}, \mathrm{NO}_{3}^{-}-\mathrm{N}\right), \mathrm{pH}$, total length of medaka, and number of spawning eggs were periodically measured for 10 months.

\section{Results \\ Nitrifying filter}

Isolation of nitrifying bacteria:Fig. 5 shows typical concentration profiles of inorganic nitrogen during isolation and development of nitrifying activities. The establishment of the nitrifying activities usually requires for a long period. In the profile, ammonium concentration was firstly increased until 22 days and rapidly decreased to almost undetectable level, where a simultaneous sharp increase in a nitrite accumulation started, indicating rapid growth of nitrite oxidizing bacteria. The nitrite accumulation continued until 46 days and sharply diminished to nearly zero. This condition indicated an establishment of the nitrifying activities and its balance, thus completed the isolation from the animal. A complete stabilization of nitrifying process requires approximately 50 days when started from non-bacteria filter as starting material. After both ammonium and nitrite concentrations reached to minimum in the water, the ammonium oxidizing activity was kept constant, $18 \mathrm{mgNH}_{4}{ }^{+}-\mathrm{N} / 100 \mathrm{~cm}^{3}$ filter/day. The result suggested that the bacterial activity was balanced with the ammonia production rate from the animal. The nitrite oxidizing activity, however, slightly lower than the ammonium oxidizing rate, the balance index was $91.4 \%$. From these results, we chose the averaged nitrifying activity for the goldfish was $16-18 \mathrm{mgNH}_{4}{ }^{+}-\mathrm{N} / 100 \mathrm{~cm}^{3}$ filter/day.

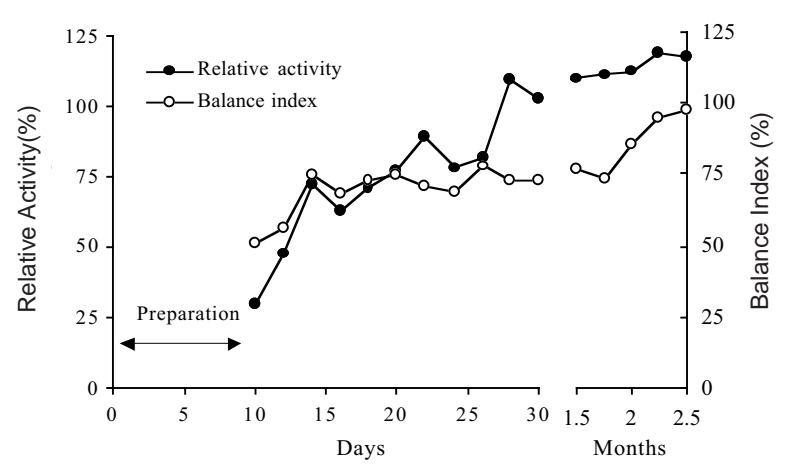

Fig.5 An activity evolution of the nitrifying filter from the seed bacteria after $1 / 10$ of seed Siporax.

Solid circle: \% relative activity of ammonium oxidization, open circle: balance index: $100\left(\mathrm{VNH}_{\mathrm{NH}}-\mathrm{V}_{\mathrm{NO}}\right) / \mathrm{V}_{\mathrm{NH}}$. 


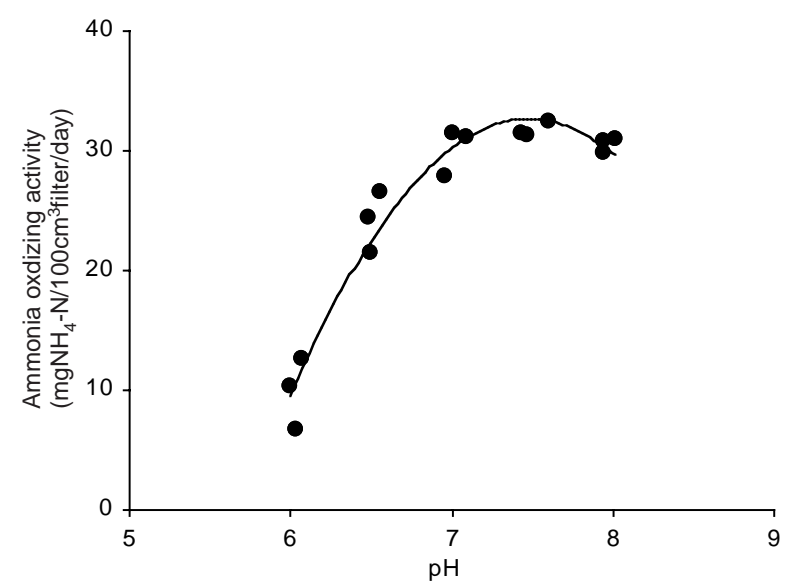

Fig.6 Effect of $\mathrm{pH}$ on nitrifying activity.

Preparation of nitrifying filter:Fig. 6 shows an activity evolution of the nitrifying filter from the seed bacteria after 1/10 of seed Siporax was mixed with new filter media with no bacteria. In this case, the original nitrifying activity of seed Siporax indicated $16.8 \mathrm{mgNH}_{4}{ }^{+}-\mathrm{N} / 100 \mathrm{~cm}^{3}$ filter/day and the balance index was $71.8 \%$, which indicated a fair bacterial balance. After the dilution of the seed material with new filter, no ammonium was added for 10 days for preadaptation. The ammonium oxidizing activities increased gradually by repeated additions of ammonium salt from 10 days. The ammonium oxidizing activity was restored to the original level of the seed filter after 28 days (10 times of ammonium additions). The nitrite oxidization appeared to recover after 14 days (3 times of ammonium additions) as judged by the balance index. The result indicated that this dilution culture method using seed filter matrix could quickly reproduce a new nitrifying filter keeping better balance than the direct bacteria isolation from fish. The filter can be used for practical use without

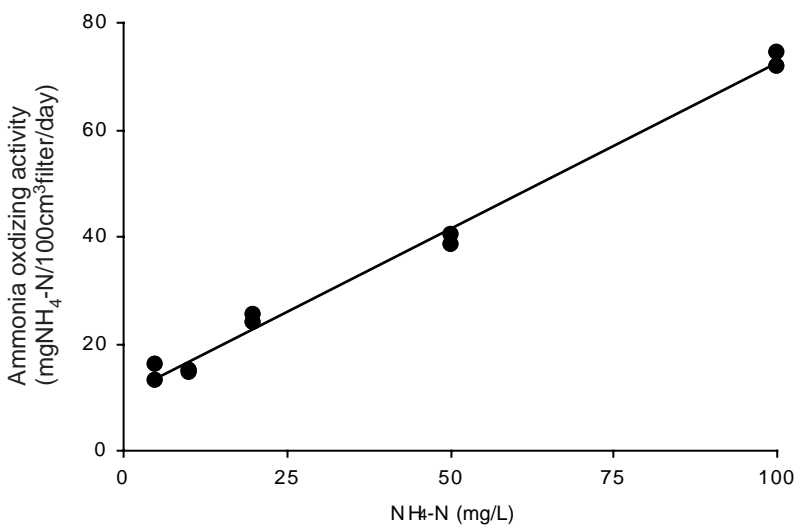

Fig.7 A correlation between nitrifying activity and added ammonium concentration.

toxic levels of neither ammonium nor nitrite accumulation after approximately one month. The complete recovery of the filter balance, however appeared to be slow than the recovery of individual process because a complete recovery of the balance index took approximately 2.5 months.

Characterization of nitrifying filter:Fig. 6 shows the $\mathrm{pH}$ dependency of the ammonium oxidizing activity of the filter. The profile indicates plateau from $\mathrm{pH} 7.0-8.0$ and drops below pH7.0 reaching to $30.2 \%$ at pH6.0 compared to $\mathrm{pH} 7.5$. A maximum activity was around $\mathrm{pH} 7.5$. The results indicated that the nitrifying activity of the filter is practically optimum in the $\mathrm{pH}$ range 7.0-8.0. When the ammonium concentration in the medium was elevated from 5 to $100 \mathrm{mgNH}_{4}{ }^{+}-\mathrm{N} / \mathrm{L}$, the ammonium oxidizing activity increased significantly up to $72.5 \mathrm{mgNH}_{4}{ }^{+}-\mathrm{N} / 100 \mathrm{~cm}^{3}$ filter/ day after 5 times repeat. Fig. 7 indicates the ammonium concentration dependency of the activities at the 5 th addition of ammonium sulfate. A linear correlation was
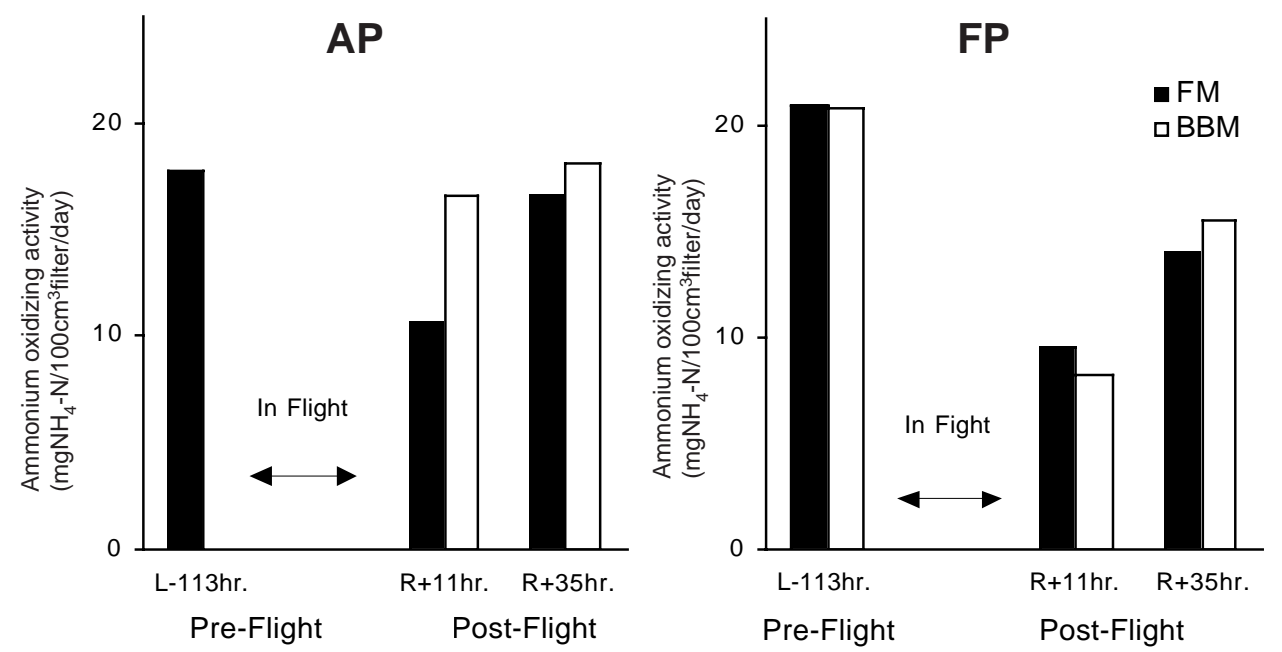

Fig.8 A comparison of ammonium oxidizing activities of biological filters used in IML-2.

The nitrifying activity was evaluated at $112 \mathrm{hrs}$ before launch and 11 and $35 \mathrm{hrs}$ after landing by additions of ammonium sulfate. FM: flight unit, BBM: ground control unit, AP included newt and medaka, FP included goldfish. 
observed between the oxidation activity and the ammonium concentration with a slope of $0.63 \mathrm{mg}-\mathrm{N} / \mathrm{mg}-\mathrm{N}$.

Nitrifying filter for IML-2 mission: The results of nitrifying activity used for the IML-2 mission are shown in Fig. 8 and 9 comparing the flight and the ground control experiments. The ground control experiment was concurrently performed with the flight experiment at Kennedy Space Center using an equivalent life support system. The nitrifying activities were evaluated at $112 \mathrm{hrs}$ prior to launch and at 11 and $35 \mathrm{hrs}$ after returned to the ground. As shown in Fig. 8, after the mission, the filter activities in the fish packages of the flight units (FM-AP, FM-FP) and the ground model (BBM-FP) decreased to 40$60 \%$ of pre-flight values. The activities, however, recovered to $70-94 \%$ of original levels after 2 nd addition of the ammonium sulfate. The activity of the filter in BBM-AP is not depicted, because no activity measurement was made. We assumed that the filter activity of the control was essentially same as the flight filter. As shown in Fig. 9, ammonium, nitrite and nitrate concentrations, $\mathrm{pH}$ and electric conductivity were continuously monitored using the ground control units. No toxic nitrogen level was found during the mission. The nitrate accumulation in a package (AP) which included newt and medaka was significantly higher than other one (FP) included goldfish, which may reflect a difference of ammonia production due to a continuous feeding in AP for medaka.
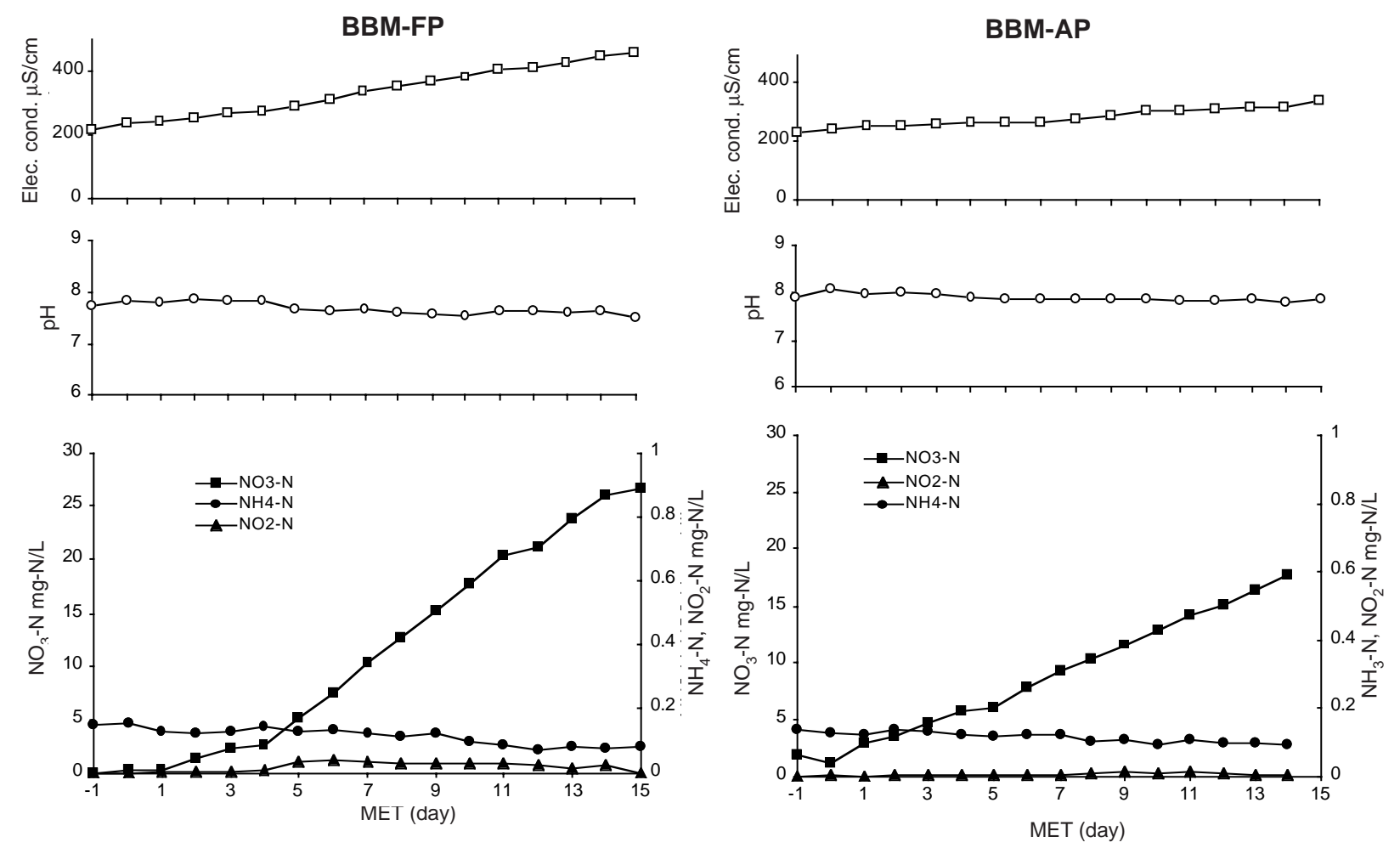

Fig.9 Water environment during IML-2 mission in the ground control unit (BBM).

AP included newt and medaka, FP included goldfish, upper figure: electric conductivity, middle figure: water $\mathrm{pH}$, lower figure: solid square; nitrate concentration, solid circle; ammonium concentration, solid triangle; nitrite concentration.

\section{Combined aerobic nitrifying and denitrifying filter}

Isolation and culture of denitrifying bacteria:The denitrifying reaction on intact and boiled rice straws soaked in water activated in 3 to 4 days after addition of an appropriate concentration of nitrate. The activity of boiled rice straw increased rapidly and remained constant. On the other hand, the activity on the intact rice straw was lower and unstable than the boiled one. When using the boiled straw, the nitrate concentration did not decreased below $4 \mathrm{mgNO}_{3}{ }^{-}-\mathrm{N} / \mathrm{L}$. The boiled treatment also gave highly reproducible results on the denitrifying activity. The denitrifying process on the rice straw has an advantage that it does not require an anaerobic condition and also the boiling is a simple method for the bacteria isolation commonly used for food processing with Bacillus sp. with the same plant.

Fig.10 shows a typical evolution of the denitrifying activity in culture with $10 \mathrm{~g}$ of rice straw. When the activity was evaluated by consumption rates of $20 \mathrm{mg}-\mathrm{N} / \mathrm{L}$ of potassium nitrate addition, it remained stable around $25 \mathrm{mgNO}_{3}{ }^{-}-\mathrm{N} / 10 \mathrm{~g}$-rice straw/day for 13 days, and decreased gradually during 36 days. The decline of the activity may be lack of metabolic carbon sources for the reaction. Although the denitrifying activity was limited in time, the rice straw was useful filter matrix considering the simplicity and reproducibility. Considering the effectiveness of the denitrifying process, $1 \mathrm{~g}$ of $\mathrm{NO}_{3}^{-}-\mathrm{N}$ requires only $19.5 \mathrm{~g}$ of rice straw to convert it to nitrogen gas.

BBM-AP
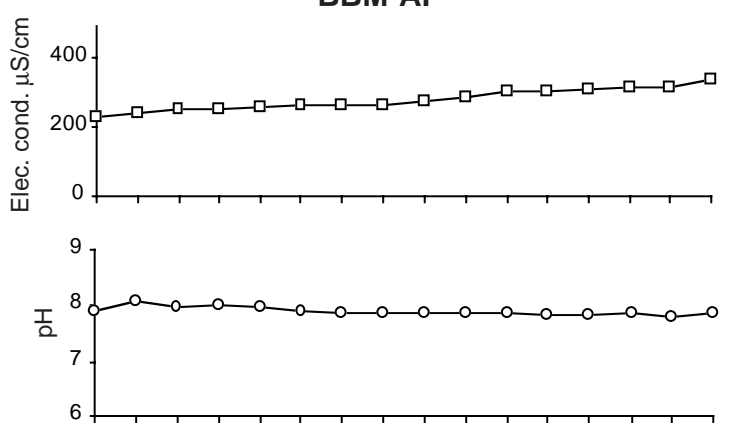


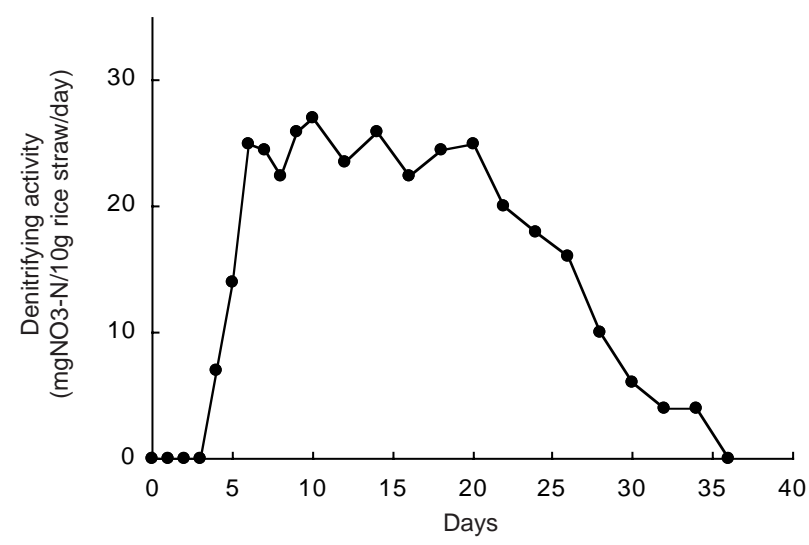

Fig.10 Evaluation of denitrifying activity of the combined biological filter in prolonged cultivation.

Nitrifying and denitrifying processes:Fig.11 shows typical responses of two types of combined filter systems one of which has higher denitrifying activity than nitrifying activity, and the other is the opposite case. Comparing these filter systems, it is clearly said that the efficient combined filter must have a higher denitrifying activity than the nitrifying activity. As shown in the figure (left), when the
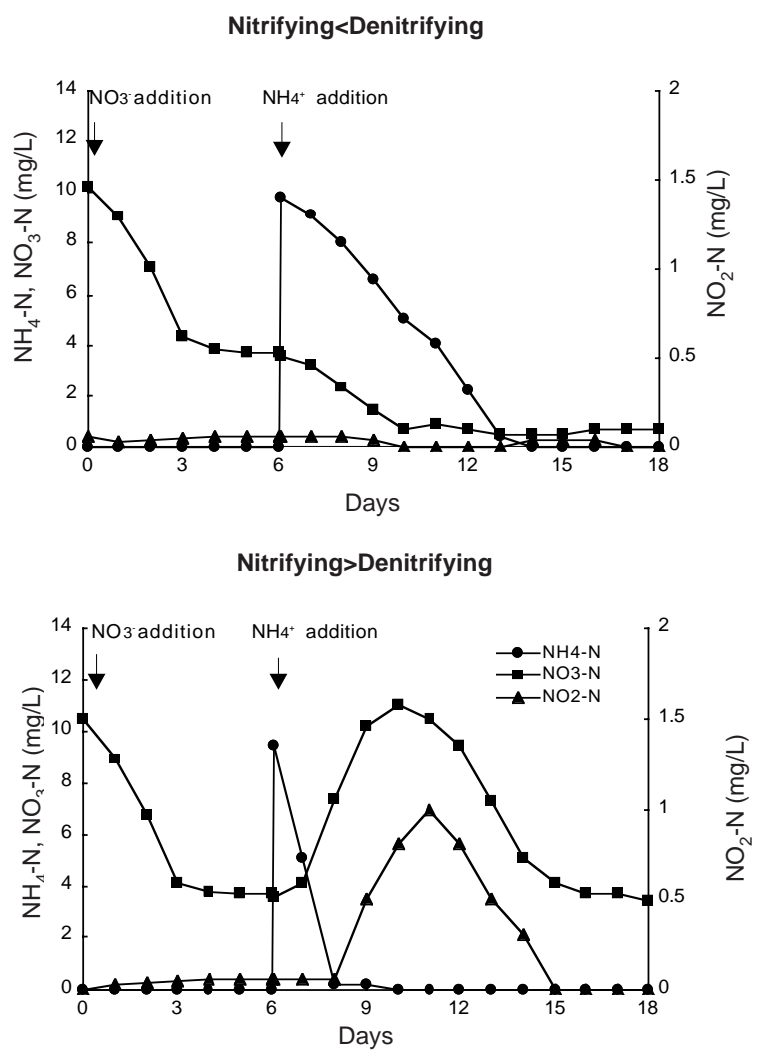

Fig.11 A comparison of two types of combined filter systems with different nitrifying/denitrifying ratios. Left: denitrifying/ nitrifying $>1$, right: denitrifying/nitrifying $<1$, solid circle: ammonium concentration, solid triangle: nitrite concentration, solid square: nitrate concentration. denitrifying activity was higher than the other, both ammonium and nitrate concentrations monotonically decline after its addition without increase in the intermediate compound. On the other hand, in the case of opposite activity combination, the accumulation of intermediate compound, nitrite or nitrate, was remarkable as shown in the same flight (right). We also found an interesting phenomenon that denitrifying process alone could not perfectly remove nitrate, because nitrate concentration did not drop below $4 \mathrm{mgNO}^{-}-\mathrm{N} / \mathrm{L}$. in both filters when only potassium nitrate was added. It however reached below $1 \mathrm{mgNO}^{-}-\mathrm{N} / \mathrm{L}$ when ammonium sulfate was added after the addition of potassium nitrate as shown in the left figure. It is then suggested that the two types of bacteria may have a cooperative property in the active states.

In this paper, we however could not resolve how those bacteria work cooperatively. One possible interpretation is a physical distance between the bacteria when colonized on the same matrix for efficient product utilization in the sequential reactions. Another possibility is local oxygen depression when nitrifying bacteria consume most of oxygen in active state, in case, the denitrifying bacteria may have a higher efficiency under the anaerobic environment.

When a constant amount of ammonium sulfate was added to the combined filters ( $10 \mathrm{~g}$ of rice straw) in different intervals, 3, 6 and 9 days, the balanced activities of the filter could be maintained for 1,2 and 3 months respectively. Under the three conditions, the total amounts of reduced nitrate were $444 \pm 58 \mathrm{mgNO}_{3}{ }^{-} \mathrm{N}$ in 3 days interval, $440 \pm 32 \mathrm{mgNO}_{3}{ }^{-} \mathrm{N}$ in 6 days interval, and $437 \pm 46 \mathrm{mgNO}_{3}-\mathrm{N}$ in 9 days interval. The results indicated that the averaged total consumption of nitrate was approximately the same $(440 \mathrm{mg}-\mathrm{N})$ on utilizing $10 \mathrm{~g}$ of the rice straw.

\section{Nitrate toxicity on medaka development}

Fig.12 shows a survival curve when just hatched medaka fry were acutely exposed to the nitrate where the

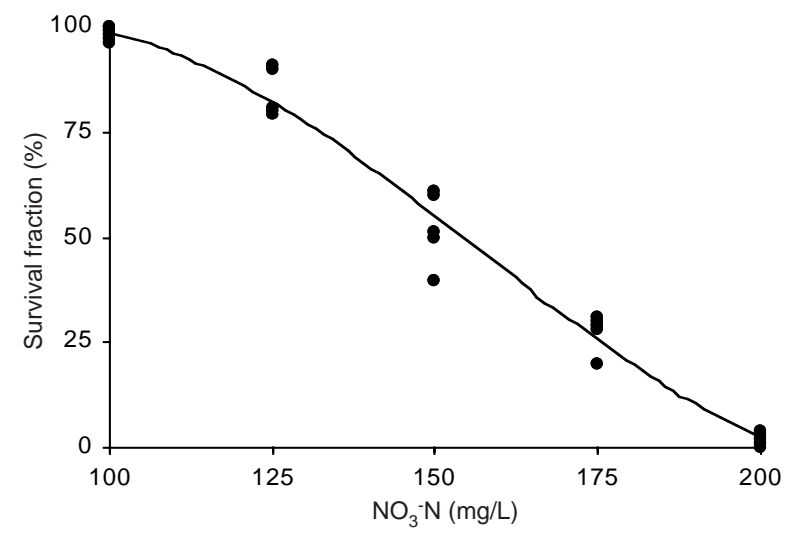

Fig.12 A survival curve on acute toxicity of nitrate to medaka fry of just hatched.

The LC50 was $156 \mathrm{mgNO}^{-}-\mathrm{N} / \mathrm{L}$ analyzed by Probit analysis $(\mathrm{n}=5)$. 
survival fraction after 96 hrs sharply decreases above $100 \mathrm{mgNO}_{3}{ }^{-}-\mathrm{N} / \mathrm{L}$ to zero in $200 \mathrm{mgNO}_{3}{ }^{-} \mathrm{N} / \mathrm{L}$. Table 2 summarizes the results on the acute toxicity and the hatching retardation. The $\mathrm{LC}_{50}$ values on three different stages, just hatching, one and two months after hatching,

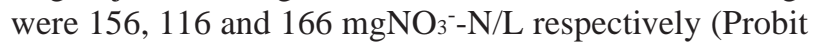
analysis). We also found a retardation of hatching depended on the nitrate concentrations. The hatching retardation was not observed until $150 \mathrm{mgNO}_{3}{ }^{-} \mathrm{N} / \mathrm{L}$ of nitrate concentration, 9-10 days after fertilization as found in no nitrate environment. When the nitrate concentration was increased to $200 \mathrm{mgNO}_{3}{ }^{-}-\mathrm{N} / \mathrm{L}$, the delay was $4-5$ days in $40-50 \%$ of the eggs and 5-7 days in more than $95 \%$ of eggs at $250 \mathrm{mgNO}_{3}{ }^{-}-\mathrm{N} / \mathrm{L}$. The success of hatching was also decreased to $60 \%$ at $250 \mathrm{mgNO}^{-}-\mathrm{N} / \mathrm{L}$.

\section{Egg-to-egg experiment of medaka}

Egg-to-egg experiments of medaka were performed using two types of filter, combined filter with both nitrifying and denitrifying activities and conventional nitrifying filter for 10 months. The results of the experiments are summarized in Fig. 13. In case of the combined filter, a maximum concentration of nitrate was $6.6 \mathrm{mgNO}_{3}{ }^{-}-\mathrm{N} / \mathrm{L}$ during entire period. On the other hand, in case of nitrifying filter, the nitrate gradually accumulated up to $58.0 \mathrm{mgNO}_{3}^{-}$ $-\mathrm{N} / \mathrm{L}$ at the end of test period. Major source of the inorganic nitrogen was from the feed for medaka. In both cases the
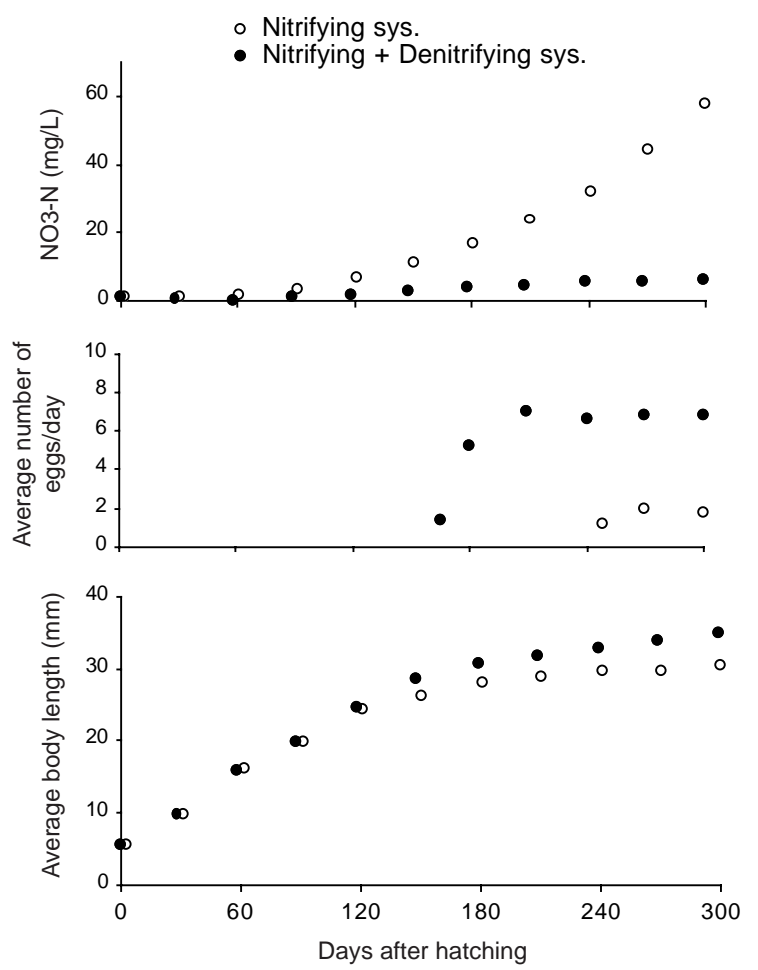

Fig.13 Toxicological effects of nitrate to medaka.

Upper figure: nitrate concentration; middle figure: average number of spawning eggs per day, lower figure: average body length of medaka, open circle: with nitrifying filter, solid circle: with combined filter. ammonium and nitrite concentrations were found to be negligible. Although, complete egg-to-egg experiments of medaka were accomplished in both cases, we found clear differences in the growth rate and spawning capability depending on the filters performance regarding nitrate removal. The growth of fry with a nitrifying filter was suppressed above $15 \mathrm{mgNO}_{3}{ }^{-}-\mathrm{N} / \mathrm{L}$ of nitrate comparing to the fry with the combined filter. An averaged body length of the fry at 10 months after hatching in the combined filter system was $34.3 \pm 1.7 \mathrm{~mm}$, whereas the other group showed $31.0 \pm 2.8 \mathrm{~mm}$. The difference between those values was statistically significant $(\mathrm{p}<0.05$, Student's $t$-test). In the nitrifying filter system, the spawning retarded than in combined filter system, and also the total number of laid eggs was fewer than in the combined filter system. The results imply that a severe waste management must be applied to remove all possible inorganic nitrogen components from the water especially for sensitive research purposes.

\section{Discussions and Conclusion}

\section{Nitrifying filter}

Nitrifying filter on which nitrifying bacterial were colonized and provided balanced oxidation reactions was successfully prepared by isolating the bacteria from goldfish. The portion of the balanced filter then cultured with new filter media to reestablish the full nitrifying activity and its balance within a month. In the isolation process of the bacteria onto the filter media from goldfish, the two types of nitrifying bacteria could not concurrently grow as seen in ammonium and nitrite accumulation profiles. As generally reported, an establishment of nitrifying activity in a new aquarium with fish started from the ammonia oxidation first, and then the nitrite oxidation. Once the nitrifying activity is established and balanced on the filter matrix such as Siporax, it becomes stable and can be divided for an expansion culture with new filter matrix without severe loss of balance in much shorter time than the original isolation. To maintain the filter activity and the expansion of the filter volume, the co-culture method with fish was found to be useful considering the reproducibility and the stability. The activity of filter without the fish slowly declined with time even ammonium salt was added periodically (unpublished data). It took approximately 30 days to fully reestablish the nitrifying capability by the co-culture method when conducted at optimum $\mathrm{pH}$ range of the filter, $\mathrm{pH} 7.0-8.0$. Our result is a good agreement with previous reports (Wild et al., 1971; Srinath et al., 1976 ). The bacterial filter is an effective method when applying to a closed aquarium, however nitrifying reaction reduces the water $\mathrm{pH}$ (Meiklejohn, 1954), which is also an important factors for aquatic animals. It is reported that goldfish is acceptable in a pH6.58.5 range for maintaining their health (Kojima, 1982). The activity of filter gradually decreased blow $\mathrm{pH} 7.0$ and almost no activity at pH6.0. The activity of the nitrifying filter 
seems to meet an optimum $\mathrm{pH}$ range of freshwater fishes because they are originally isolated from goldfish. The advantage of the biological filter is a self-adaptive system responding to ammonium production rate of animals. The dynamic range of the filter activities is however not well understood experimentally. A result which we achieved a maximal nitrifying activity of $72.5 \mathrm{mgNH}_{4}{ }^{+}-\mathrm{N} / 100 \mathrm{~cm}^{3}$ filter/day is extremely high, and may imply a possibility of further active system.

\section{Nitrifying filter of IML-2 mission}

Successful results were obtained by applying the nitrifying filter to the space experiments, IML-2, using goldfish, newt and medaka. Both newt and medaka laid eggs in space and developed normally, and goldfish were kept quite healthy on the entire mission period (Ijiri, 1995; Mogami et al. 1996; Takabayashi et al., 1997). The fact indicated undoubtedly that the nitrifying filter used in the experiments was very effective to maintain the water quality. In the ground control facility concurrently operated, neither toxic ammonia nor nitrite was found during mission. The activity of filters decreased to $40-60 \%$ in both flight and ground control device after the mission indicating an adaptation of bacteria depending on the ammonia production rates of internal animals. We also found that load factors of the filter, the ratio of the filter capability to nitrogen production rate, were the same in the two filters, 3.6 for BBM-AP and 3.5 for BBM-FP. These load factors are in good agreement with the value, 3.6, reported as a result of Neurolab mission (Nagaoka et al., 1998). In this mission, the life support system employed a similar type of nitrifying filter, but in saltwater. The paper also reported a similar recovery of the nitrifying activity by additions of ammonium chloride after experiment as seen in the Fig.8.

\section{Nitrate toxicity}

It is normally considered that nitrate, as an oxidized product of ammonia by nitrifying bacteria, is nontoxic compound to aquatic animals in regular aquarium environment. An accumulation of the nitrate however decreases $\mathrm{pH}$ of water resulted in a possible cause of fish acidosis (Post, 1983; Stoskof, 1993) and same time decreases in the nitrifying activity (Wild et al., 1971; Srinath et al., 1976). In this study, the LC50 value of nitrate at 96 hrs in different stages of medaka fry after hatching was found to be low, 116-166mgNO $3^{-}-\mathrm{N} / \mathrm{L}$. The concentration obtained from the acute lethal tests of nitrate also induced a delay of hatching time and lowered the hatching capability. In addition, nitrate, even in a low concentration, affects the growth of medaka fry during a prolonged exposure such as in the egg-to-egg experiment. From these results, the maximal allowance of nitrate concentration to medaka was suggested to be $20 \mathrm{mgNO}_{3}{ }^{-} \mathrm{N} / \mathrm{L}$ which is a much lower concentration than ordinary thought. It is also considered that the egg-to-egg experiment in space environment in a closed system will be a technical challenge not only in the severe water quality control, but also in the engineering point of view.

\section{Combined filter}

The finding of the aerobic denitrifying bacteria on rice straw allows us to improve the biological filter system to combine both nitrifying and denitrifying processes under aerobic environment. The idea of the combined filter utilizing rice straw is quite unique and it effectively removes all inorganic nitrogen wastes in the water under aerobic condition similarly in nature. At first, we tested whether or not both bacteria types could coexist on the same matrix. The result was suitable for the simultaneous processes to convert ammonia to nitrogen gas on the filter, and further more, both nitrifying and denitrifying reactions seemed to be coupled each other to enhance the efficiency.

In space, a life support system of aquatic animals must facilitates the both nitrifying and denitrifying processes for the efficient water quality management because of the severe constraints of available volume and water containment to be complete closed. Although some commercial products which mention a denitrifying capability are available, but none of them are well defined nor verified by the experimental data. This was why we began to investigate more stable bacterial filter including denitrifying process working under aerobic conditions.

In the view of space application where very restricted laboratory area is available, the compactness and the manageability of equipment will be the prioritized issue. The combined filter utilizing rice straw can be applied under such environment. The filter works quite high throughput under aerobic condition having self-provided a carbon source for the denitrifying reaction. Compared with existing nitrogen removal techniques, the merits may expand the potential application not only for space, but also for any aquarium, although there is a limited supplemental carbon source from rice straw. As a future task, we will investigate more detailed mechanisms of the bacterial ecosystem and hope to establish a biological filter system which has longer lifetime.

\section{References}

Blaszczyk, M., Mycielski, R., Jaworowska-Deptuch, H. and Brzostek, K. (1980) Effect of Various Sources of Organic Carbon and High Nitrite and Nitrate Concentrations on the Selection of Denitrifying Bacteria - I. Stationary Cultures. Acta. Microbiol. Pol. 29, 397-406.

Davies, T. R. and Toerien, D. F. (1971) Population Description of Denitrifying Microbial System. Water Res. 5, 553-564.

Ijiri, K. (1995) The First Vertebrate Mating Experiment in Space - A Fish Story. Tokyo, RICUT.

Beside this full-colored book, there also exists a video tape of 30 min length 'A Video Version of The First Vertebrate Mating in Space - A Fish Story' (K. Ijiri, 1997, RICUT. Tokyo, Japan). The book and video tapes are available, without any charge when you request to the author, clearly stating your name and mailing address. His postal address: Dr. Kenichi Ijiri, Radioisotope Center, University of Tokyo, Yayoi, Bunkyoku, Tokyo 113-0032, Japan; E-mail: ijiri@ ric.u-tokyo.ac.jp Fax +81-3-5841-3049. 
Kojima, Y. (1982) 4. Fishes. In Laboratory biology vol. 1 (ed. Egami, N. and Katsumi, M.) pp. 97-113. Tokyo, Maruzen.

Meiklejohn, J. (1940) Anaerobic Denitrification. Ann. Appl. Microbiol., 558-575.

Meiklejohn, J. (1954) Some Aspects of the Physiology of the Nitrifying Bacteria. Symp. Soc. Gen. Microbiol., 4, 68-83.

Mogami, Y., Koike, H., Yamasihta, M., Izumi-Kurotani, A. and Asashima, M. (1996) Early Embryogenesis of Amphibians in Space: AstroNewt for the Space Embryology in IML-2 and SFU. Adv. Astron. Sci., 91, 1089-1097.

NASDA (1996) 2. Development Results of Experimental Hardware. In NASDA Technical Memorandum, Final Report of IML-2 Experiments (NASDA-TMR-960049) pp. 1983.Tokyo, NASDA.

Post, G. (1983) Textbook of Fish Health. New Jersey, T.F.H. Publications.

Nagaoka, S., Matsubara, S., Kato, M., Uemura, M., Uchida, S. and Ogawa, N. (1998) Water Quality in VFEU Life Support System during the Neurolab Flight. Biol. Sci. Space, 12, 216217.

OECD (1981), OECD Guidelines for Testing Chemicals. Paris, OECD.

Shimura, R., Kumagai, H., Kozu, H., Amano, T. and Nagaoka, S. (1995) Preparation of Nitrifying Bacteria for Water Management of Aquatic Experiment in Space. Proceedings of the Twelfth Space Utilization Symposium, 148-151.

Stoskof, M. K. (1993) Chapter 65. Environmental Requirements of Freshwater Tropical Fishes. In Fish Medicine (ed. Stoskof, M. K.) pp. 545-553. Philadelphia, W.B. Sunders Company.

Srinath, E. G., Loehr, R. C. and Prakasam, T. B. S. (1976) Nitrification Organism Concentration and Activity. J. Environ. Eng. Div. Am. Soc. Civ. Eng., 102, EE2, 449-463.

Takabayashi, A., Ohara, K., Ohmura, T., Watanabe, S., Mori, S., Tanaka, M. and Sakuragi, S. (1997) Mechanism of Vestibular Adaptation of fish under Microgravity, Biol. Sci. Space, 11, 351-354

Rhee, G. J. and Fuks, G. W. (1978) Waste Water Denitrification with One Carbon Compounds as Energy Source. J. Wat. Pollut. Control Fed. 50, 2111-2119.

Rhodes, M., Best A. and Payne, W. J. (1963) Electron Donors and Cofactors for Denitrification by Pseudomonas perfectomarinus. Can. J. Microbiol. 9, 799-807.

Wild, H. E., Sawyer, C. N. and McMahon, T. C. (1971) Factors Affecting Nitrification Kinetics, J. Wat. Pollut. Control Fed., 43, 1845-1854. 